\title{
Nye norske retningslinjer for resynkroniseringsterapi ved hjertesvikt
}

\author{
Nylig er det publisert norske retningslinjer for behandling av hjertesvikt med kardial resynkroniseringsterapi. \\ Vi mener flere bør henvises til denne behandlingen som både øker overlevelse, bedrer livskvalitet og reduserer \\ antall liggedøgn i sykehus hos pasienter med hjertesvikt.
}

Retningslinjene er utarbeidet av Norsk Cardiologisk Selskap gjennom arbeidsgruppene for hjertesvikt og hjerterytmer og i samarbeid med alle sentre som tilbyr kardial resynkroniseringsterapi. De er så godkjent av styret i Norsk Cardiologisk Selskap og nylig publisert i Tidsskriftet (1). Dokumentet er utarbeidet av et bredt kardiologisk fagmiljø og bør være av interesse for alle leger i Norge som behandler pasienter med hjertesvikt.

\section{Hjertesvikt og kardial resynkroniseringsterapi}

Kronisk hjertesvikt er en alvorlig tilstand med høy dødelighet og med en forekomst på $1-3 \%$ av befolkningen i den vestlige verden $(1,2)$. Årlig vil ca. $2,5 \%$ av befolkningen i 60 -årsalderen rammes. Opp mot ca. $35 \%$ av pasienter med moderat eller alvorlig hjertesvikt har venstre grenblokk med QRS-bredde > $120 \mathrm{~ms}(1,2)$. Ved alvorlig hjertesvikt vil grenblokk gi en asynkron ventrikkelkontraksjon som igjen fører til endret form og struktur av hjertet (remodulering) og betydelig forverret prognose (1).

Kardial resynkroniseringsterapi er et biventrikulært pacemakersystem som resynkroniserer en asynkron venstre ventrikkelkontraksjon grunnet intraventrikulær eller interventrikulær ledningsforstyrrelse. Systemet implanteres ved at en pacemakerledning plasseres via sinus coronarius i en koronarvene over laterale del av venstre ventrikkel og en ledning endokardialt i høyre ventrikkel. Hos pasienter med sinusrytme implanteres en ledning til høyre atrium for sensing av egenrytme og for å synkronisere AV-overledningen. Biventrikulær pacing reverserer/ motvirker remoduleringsprosessen, øker fylningstiden i venstre ventrikkel, reduserer både mitralinsuffisiens, endediastolisk og endesystolisk volum samt bedrer ejeksjonsfraksjonen (1). Et biventrikulært pacemakersystem kan implanteres med eller uten hjertestarterfunksjon og kalles da henholdsvis CRT-D eller CRT-P. Inngrepet gjøres i lokalanestesi med normalt bare ett liggedøgn i sykehus, men prosedyren krever erfaren operatør for å oppnå et godt resultat og lavest mulig komplikasjonsrate.

\section{EKG og ejeksjonsfraksjon}

For å ha nytte av kardial resynkroniseringsterapi kreves symptomer og kliniske funn typisk for hjertesvikt i kombinasjon med redusert ejeksjonsfraksjon. I de nye norske retningslinjene må pasientene ha symptomer tilsvarende New York Heart Association (NYHA)-funksjonklasse II-IV og ha ejeksjonsfraksjon $\leq 35 \%$ målt med ultralyd (1). Pasienter med kronisk atrieflimmer bør ha symptomer i NYHA- klasse III-IV.

Dyssynkroni målt med ultralyd inngår ikke i de nye retningslinjene for utvelgelse av pasienter til kardial resynkroniseringsterapi, da dette ikke er vist å predikere respons. Pasientene må imidlertid ha et breddeforøket QRS-kompleks $\geq 120 \mathrm{~ms}$ i EKG som tegn på forsinkelse i hjertets ledningssystem. Pasienter med tydelig venstre grenblokk eller med en komponent av venstre grenblokk i form av intraventrikulcert blokk er de som er vist å profittere mest på kardial resynkroni-

\section{«Vi mener flere bør henvises til denne behandlingen»}

seringsterapi både med reduksjon av mortalitet og morbiditet. Pasienter med rent høyre grenblokk har generelt liten effekt av denne behandlingsformen. Dette tydeliggjøres sterkere i disse nye norske retningslinjene sammenliknet med tidligere internasjonale retningslinjer for denne behandlingen da kun de med venstre eller intraventrikulært grenblokk har fått den sterkeste anbefalingen for kardial resynkroniseringsterapi (dvs. anbefalt både for reduksjon av mortalitet og morbiditet). En subgruppe av pasienter med uttalte symptomer og uspesifikt grenblokk har fått en svakere anbefaling, men kan vurderes fordi noen av disse pasientene kan profittere symptomatisk.

\section{Behov for konvensjonell pacemaker} Bruk av konvensjonell pacemaker, med pacing i høyre ventrikkel, gir unormal aktivering og dyssynkroni som likner det man ser ved nativt venstre grenblokk. Flere studier har vist at høy grad av høyre ventrikkel-pacing er assosiert med økt grad av hjertesvikt. For pasienter med konvensjonell pacemaker og høy grad av ventrikkelpacing som utvikler svikt bør man derfor $\mathrm{i}$ henhold til de nye norske retningslinjene sterkt vurdere oppgradering til kardial resynkroniseringsterapi. Videre bør man $i$ henhold til de nye retningslinjene hos pasienter med kun lett redusert venstre ventrikkel-funksjon (ejeksjonsfraksjon $<45 \%$ ) og indikasjon for pacemaker pga. bradykardi og forventet høy grad av ventrikkelpacing, vurdere implantasjon av kardial resynkroniseringsterapi direkte (1).

\section{For få pasienter henvises}

Basert på data fra to store EuroHeart Failureundersøkelser og kriteriene i de nye retningslinjene anslår man at ca. 5-10\% av hjertesviktpopulasjonen vil kunne profittere på kardial resynkroniseringsterapi (2). Dette er en begrenset andel av populasjonen, men blir likevel mange pasienter grunnet høy insidens og prevalens av hjertesvikt. Hvis man ser på de samme studiene og ekstrapolerer fra utskrivningsdata, bør implantasjonsraten kunne ligge opp mot 3-400 implantasjoner/ million innbyggere/år i Europa (3). Siste års rate i Norge var 76 implantasjoner/million, som er vesentlig mindre enn f.eks. Danmark, der raten var 170 implantasjoner/million (4). Flere pasienter bør derfor henvises til denne behandlingen. Den øker overlevelse, bedrer livskvalitet og reduserer antall liggedøgn i sykehus for pasienter med hjertesvikt (1).

\section{Torbjørn Holm \\ torbjorn.holm@rikshospitalet.no Erik Kongsgård}

\footnotetext{
Torbjørn Holm (f. 1968) er spesialist i indremedisin og i hjertesykdommer, med spesialkompetanse innen arytmibehandling og hjertesvikt. Han er dr.med., overlege ved Arytmiseksjonen, Kardiologisk avdeling, Oslo universitetssykehus, Rikshospitalet, og sitter i arbeidsgruppen for arytmier i Norsk Cardiologisk Selskap. Forfatter har fylt ut ICMJE-skjemaet og oppgir ingen interessekonflikter.
}

Erik Kongsgård (f. 1955) er spesialist i hjertesykdommer, med hjerterytmeforstyrrelser som subspesialitet. Han er seksjonsoverlege for Arytmiseksjonen ved Oslo universitetssykehus, Rikshospitalet og er formann for Norsk Cardiologisk Selskaps arbeidsgruppe for arytmibehandling. Forfatter har fylt ut ICMJE-skjemaet og oppgir følgende interessekonflikter: Han har mottatt forskningsstøtte fra Medtronic og vært styremedlem i St. Jude. 


\section{Litteratur}

. Holm T, Færestrand S, Larsen Jl et al. Kardia resynkroniseringsterapi ved hjertesvikt - norske retningslinjer. Tidsskr Nor Legeforen 2014: 134.

2. Boriani G, Kranig W. Donal E et al. A randomized double-blind comparison of biventricular versus eft ventricular stimulation for cardiac resynchronization therapy: the Biventricular versus Left Univentricular Pacing with ICD Back-up in Heart Failure Patients (B-LEFT HF) trial. Am Heart 2010; 159: 1052-8, e1

3. Liang Y, Pan W, Su Y et al. Meta-analysis of randomized controlled trials comparing isolated left ventricular and biventricular pacing in patients with chronic heart failure. Am J Cardiol 2011 108: $1160-5$

4. Aruiccio A, Kuch KH, Hatla R et al. The current status of cardiac electrophysiology in the ESC member countries. The EHRA White book, 2013. www.escardio.org/communities/EHRA/ publications/Pages/white-book-project.aspx (17.6.2014)

Mottatt 9.5. 2014, første revisjon innsendt 2.6. 2014, godkjent 17.6. 2014. Redaktør: Siri Lunde Strømme.

Publisert først på nett.

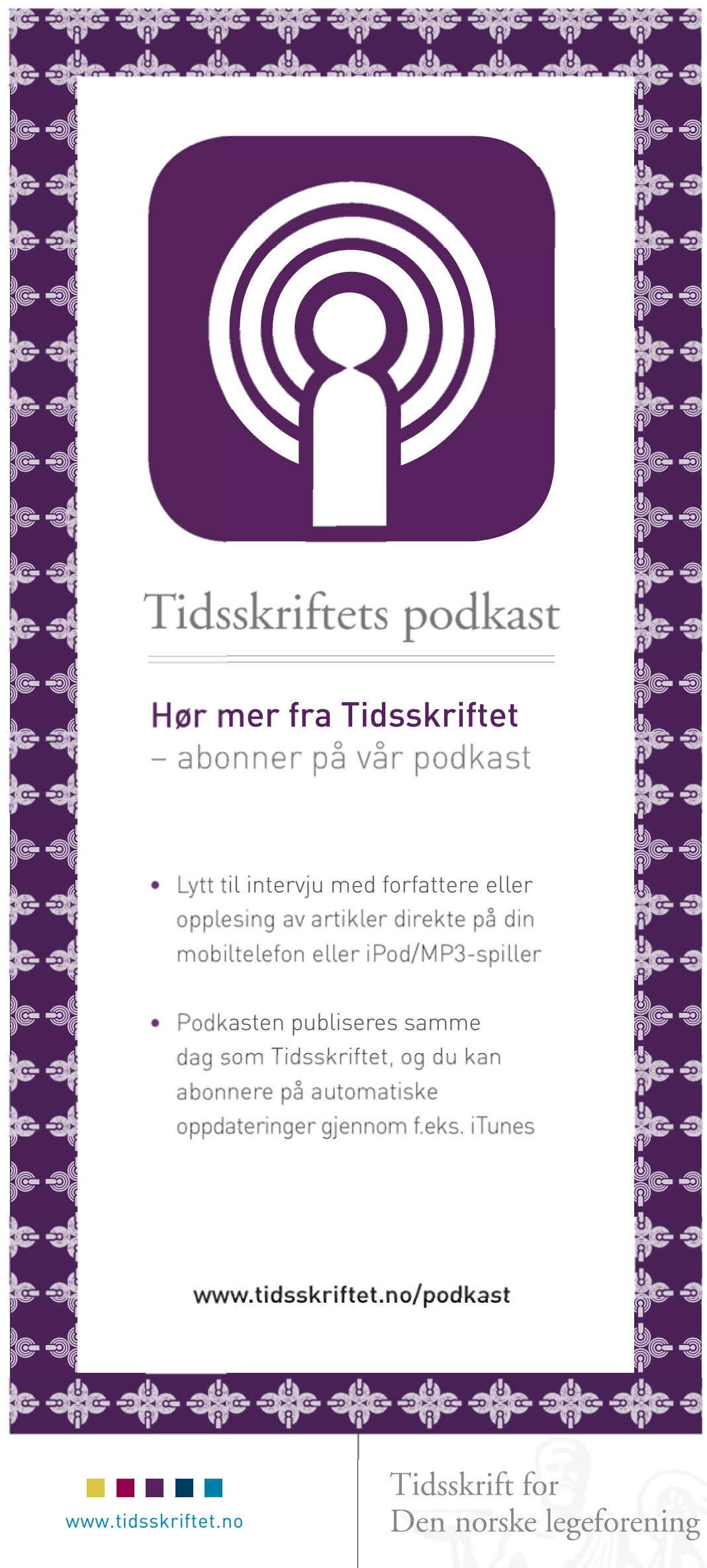

